\title{
PSYCHORHEOLOGY OF FOOD DISPERSIONS
}

\author{
PETR ŠTERN ${ }^{1)^{*}}$, ZDEŇKA PANOVSKÁ $^{2)}$, JAN POKORNÝ2) \\ ${ }^{1)}$ Institute of Hydrodynamics, Academy of Sciences of the Czech Republic, v. v. i., Pod Pat'ankou 5, Prague 6, \\ 16612 Czech Republic; *Corresponding author, Mailto: stern@ih.cas.cz, Phone:+ 420233109 072, Fax: + 420233324361. \\ ${ }^{2)}$ Institute of Chemical Technology, Prague, Department of Food Chemistry and Analysis, Technická 5, Prague 6, \\ 16628 Czech Republic.
}

Food dispersions are the most frequent and most important food components. Useful information was obtained in the investigations of liquid emulsions. The results obtained in their study were compared with tomato ketchups. They were chosen as an example of food dispersions with low lipid content. A set of 20 samples of tomato ketchups purchased on the native market were analyzed by several rheological procedures (RheoStress 300) and by sensory profiling both of textural and flavour characteristics. The psychorheology was used for the determination of relationships between results of instrumental and sensory measurements. The data base obtained was processed by statistical methods. The temperature affects the results differently, but it is not useful to study temperatures below room temperature. The rheological parameters agree with the Herschel-Bulkley equation. Therefore, the psychorheology was applied as a suitable complex method. About a third of plots between two variables were significantly related. Several statistically significant relationships were obtained between rheological attributes, sensory attributes, and the combinations between rheological and a sensory attributes. Great variance in all characteristics was observed in all samples variables. Similarly as in case of lipid dispersions, the sensory texture acceptability was significantly related with the overall flavour acceptability, similarly as in case of other food dispersions. It proves the importance of texture in consumption of tomato ketchups.

KEY WORDS: Psychorheology; Food Dispersions, Tomato Ketchup; Rheology, Sensory Analysis.

Petr Štern, Zdeňka Panovská, Jan Pokorný: PSYCHOREOLOGIE POTRAVINÁŘSKÝCH DISPERZÍ. J. Hydrol. Hydromech., 58, 2010, 1; 12 lit., 6 obr.

Potravinářské disperze patří mezi nejrozšiřrenější potravinářské produkty. Potřebné informace k prezentovaným výsledkům předloženého studia byly získány předchozím studiem potravinářských emulzí. Kečupy byly vybrány jako příklad potravinářských disperzí s nízkým obsahem tuku. Bylo hodnoceno celkem 20 vzorků komerčních výrobků tomatových kečupů, zakoupených v české obchodní síti. Reologické charakteristiky byly získány pomocí rotačního reometru RheoStress 300 a texturní vlastnosti pomocí senzorické analýzy. Jako nejvhodnější metoda byla zvolena psychoreologie, která zkoumá funkční vztahy mezi reologickými parametry, stanovenými instrumentální analýzou a senzorickými charakteristikami, stanovenými senzorickou analýzou. Znalost těchto vztahů je důležitá ke kvantitativní charakterizaci tokových a deformačních dějů, probíhajících při senzorické zkoušce. Reologické parametry vyhovují stavové rovnici Herschel-Bulkley. Korelací reologických a senzorických dat byly získány v třetině př́padů těsné funkční závislosti s vysokými hodnotami korelačních koeficientů. Analýzy prokázaly velké rozdíly mezi jednotlivými vzorky kečupů. Přri nižších teplotách by se patrně projevily zřetelněji vlivy optimální textury a získaly se bližší hodnoty mezi vzorky. Stejně jako u dříve hodnocených potravinářských produktů bylo prokázáno, že textura výrazně ovlivňuje chut'ové vlastnosti, což zdůrazňuje význam textury při konzumaci rajčatového protlaku.

KLÍČOVÁ SLOVA: psychoreologie, potravinářské disperze, rajčatový kečup, reologie, senzorická analýza.

\section{Introduction}

Food emulsions and other dispersions belong to very frequent food constituents. In previous papers, we studied several food emulsions, such as fat foams (1988), margarine (1988, 2001), dressings and tartar sauce (2006). It was considered as interesting to investigate properties of tomato ketchups as example of low-lipid food dispersions. Ketchup is almost exclusively prepared from tomato juice, 
onion, vinegar, sugar, and various spices (Brummer, 2006). Because of great importance of both the rheology and sensory value, psychorheology was applied for evaluation.

Consumers prefer thick products, therefore, tomato ketchup is now prepared with addition of thickeners especially starches (potato, corn starch, modified starches). Various hydrocolloids, e.g. carboxymethylcellulose, xanthan gum, locust been gum, guar gum and traganth gum are now increasingly used (Sahin, Ozdemir, 2004).

Intensive application of thickeners results in great number of products with variable rheological properties. Therefore it would be useful to investigate relationships of texture in a larger set of commercial samples. The samples should be tested from the standpoint of psychorheology (Barnes, 1999), i.e. a combination of rheological and sensory properties.

\section{Materials and methods}

A total of 20 commercial samples of tomato ketchups were purchased at various supermarkets and immediately stored in a refrigerator. Some samples were of local production, but, other were imported. The samples were then analyzed both at $23{ }^{\circ} \mathrm{C}$ and $45^{\circ} \mathrm{C}$ (a total of 40 results). The temperature of $23{ }^{\circ} \mathrm{C}$ corresponded to the room temperature, the temperature of $45{ }^{\circ} \mathrm{C}$ corresponded to ketchup applied on hot meal.

\subsection{Rheological analysis}

Several rheological data were obtained (List of symbols). The apparent viscosity, thixotropy, storage (elasticity) modulus, loss (viscosity) modulus and the complex modulus were measured using a Rheometer RheoStress 300 (Thermo Haake, Karlsruhe, Germany) in coaxial cylinders system, equipped to prevent slipping on the walls of measuring cylinders. Flow curves were determined in the shear rate range $0-150 \mathrm{~s}^{-1}$ (the measuring time of the "up-curve" and the "down-curve" has been 60 s). Apparent viscosity $\eta_{a}$ was calculated as the ratio between shear stress $\tau$ and shear rate $\gamma$ at the maximum shear rate of $150 \mathrm{~s}^{-1}$. The yield value was determined using a vane rotor as the maximum value of the shear stress on the time axis at a constant shear rate at the vane rotor $\gamma=0.5 \mathrm{~s}^{-1}$ (Steffe, 1996).

Fresh samples were used for measuring at two temperatures. Each measurement was repeated three times.
It was found that ketchup is a viscoplastic substance from the rheological point of view. The results agree with the Herschel-Bulkley equation (Herschel, Bulkley, 1926; Roberts, 2003; Jaros, Rohm, 2003): $\tau=\tau_{\mathrm{o}}+\eta_{p l} \cdot \gamma^{n}$ (later only H-B). Regressions were measured from the "down curve" of the flow curve, i.e. after elimination of the thixotropy. As the evidence, the flow curve of the ketchup Spak Gourmet is shown in Fig. 1. Results of the regression measured on the "down-curve", following the Herschel-Bulkley equation: $\tau_{0}=17.4$ $\mathrm{Pa}, \eta_{p l}=9.6$ Pas, $n=0.395$, regression coefficient $r$ $=0.9996$. Regression coefficients in case of all samples studied at the two temperatures behaved between $r=0.999-1.0$.

Good agreement between the experimental results and the Herschel-Bulkley equation were reported from another source (Varela et al., 2003).

The existence of thixotropy of tomato ketchup is evident from Fig. 2, constructed after the procedure given by Brummer (2006).

The structural breakdown and subsequent building of the structure is explained here. The first part of the experiment was performed in a linear viscoelastic range. In the second part the strain increased sharply. This behaviour results in a significant decrease of all moduli. In the third part of the experiment the strain decreased suddenly, returning again to the original viscoelastic range, and after a few minutes both the moduli reached again their starting values. Earlier, the thixotropy of tomato ketchup was reported from another laboratory (Autio, Houška, 1991).

\subsection{Sensory evaluation}

Sensory analysis was carried out under standard conditions as specified by the respective ISO standards: The testing booths after ISO 8589, 2007; judges after ISO 8586.1, 1993; preparation and serving of samples after ISO 68589, 2005; scales after ISO 4121, 1978; the flavour acceptability after ISO 6564, 1985; the texture acceptability was determined in the same way. Each result was calculated from 12 determinations.

\subsection{Statistical methods}

Data obtained in the experiments were analyzed by ANOVA and multiple regressions using the software STATISTICA 4.0. 


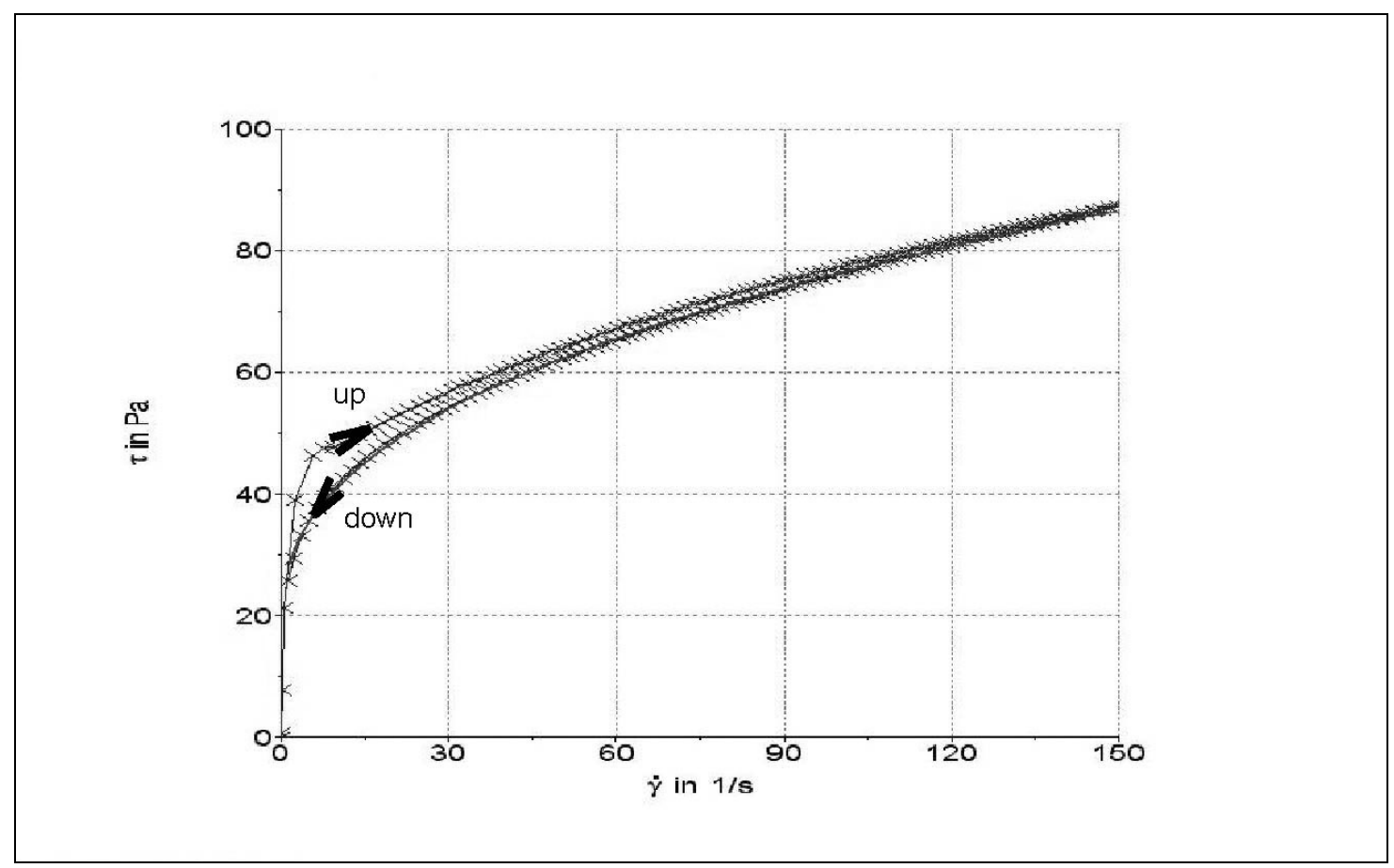

Fig. 1. Flow curve of ketchup (Spak Gourmet) $T=23^{\circ} \mathrm{C}$, regression of "down curve" $(<) \mathrm{HB}$.

Obr. 1. Toková křivka měřeného kečupu (Spak Gourmet) $T=23^{\circ} \mathrm{C}$, regrese zpětné větve tokové křivky $(<)$ H-B.

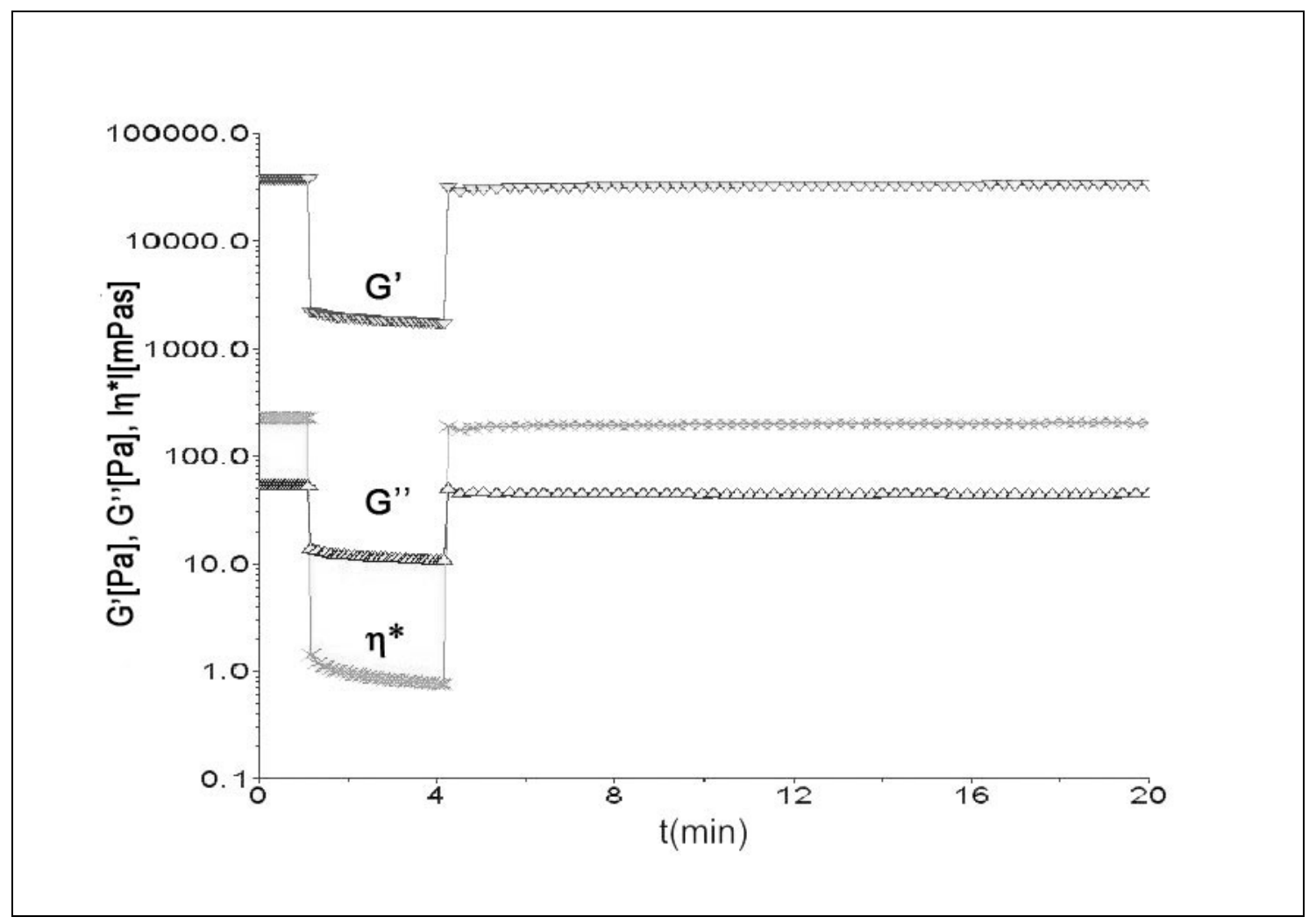

Fig. 2. Breakdown and building of structure of tomato ketchup under strain. Obr. 2. Strukturální změny tomatového kečupu vlivem deformace. 


\section{Results and discussion}

It could be expected that properties of ketchups would be very variable depending on the manufacturer's plans, which was so confirmed by experiments. Standard deviation between two evaluations of the same sample varied by $30-40 \%$ of the respective means, while the values varied between $15-20 \%$ in case of sensory evaluation. All relationships presented in Figs. 3-6 include all samples and both temperatures of $23^{\circ}$ and $45^{\circ} \mathrm{C}$.

In spite of great variability properties, the number of significant relationships $(P=0.05)$ was surprisingly high (out of 141 combinations of variables, 58 were statistically significant). Most relations were linear or very close to linearity, which may be explained by narrow range of values in the tested material. No relationship was detected between the static yield value and other variables. Great range among properties of individual samples can be explained by the assumption that the differences decrease with the decreasing temperature in case of the rheological methods than in case of sensory results. Of course, it is not useful to study temperatures lower than the room temperature as tomato ketchups are not tested by the sensory analysis among the consumers immediately after removing from the refrigerator, or if tested, they would not affect the texture acceptability.
As could be expected many relationships were found among rheological variables. An interesting example is the significant relationship between the plastic viscosity (HB) and the apparent viscosity (Fig. 3).

Relationships between the sensory characteristics are very interesting, especially sensory testing on the plate, before sample ingestion, such as between the resistance towards ladling and pouring the sample (Fig. 4). Data on the plate have been obtained before the contact of the sample with the oral cavity, i.e. under conditions close to those of the rheological measurement.

In some cases the rheological measurement can predict the sensory attribute, e.g. the storage modulus and the pouring sample from the spoon (Fig. 5) or the storage modulus and the viscosity perceived in the mouth.

Surprising is the close correlation between acceptabilities of sensory texture and overall flavour (Fig. 6). Similar relations were observed in fat foams ( fat content (Štern et al., 2001), yoghurt mayonnaise (Śtern et al., 2008) or tartar sauce (Štern et al., 2006). The data prove the importance of texture percept for the overall flavour evaluation.

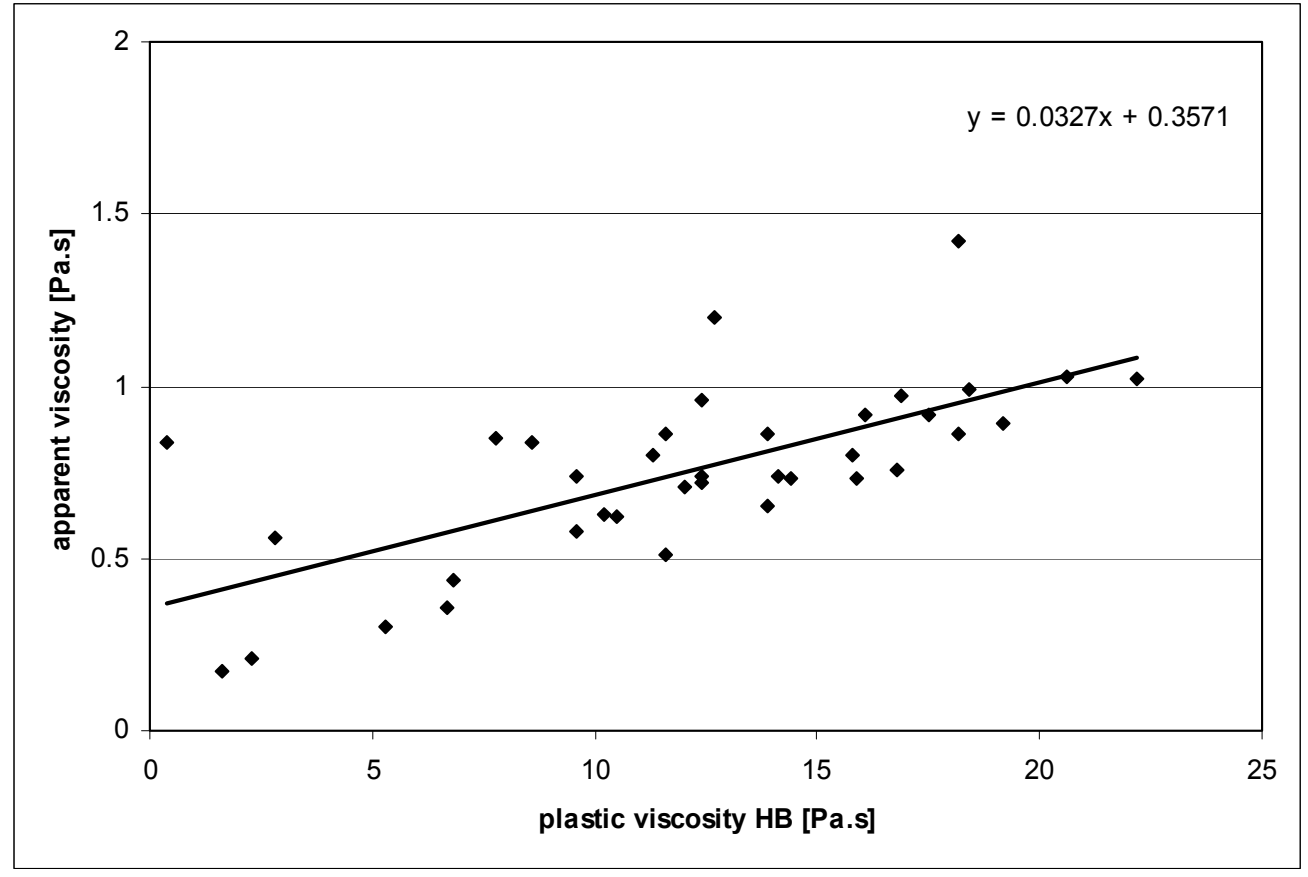

Fig. 3. Relationship between the plastic viscosity (H-B) and the apparent viscosity. Obr. 3. Závislost mezi plastickou viskozitou (H-B) a zdánlivou viskozitou. 


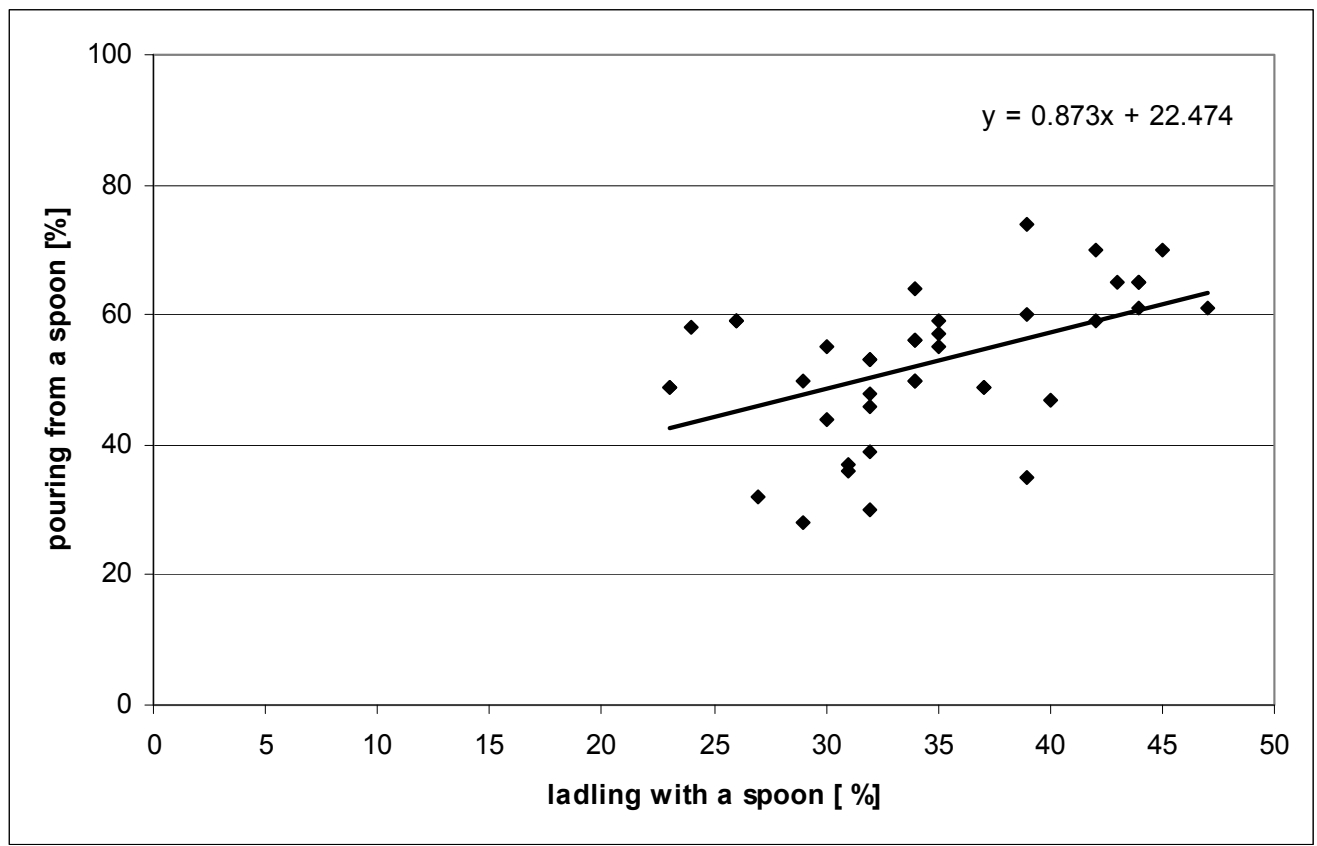

Fig. 4. Resistance of ketchups on ladling with a spoon and pouring from a spoon. Obr. 4. Odpor kečupu při nabírání lžící a stékání se lžíce.

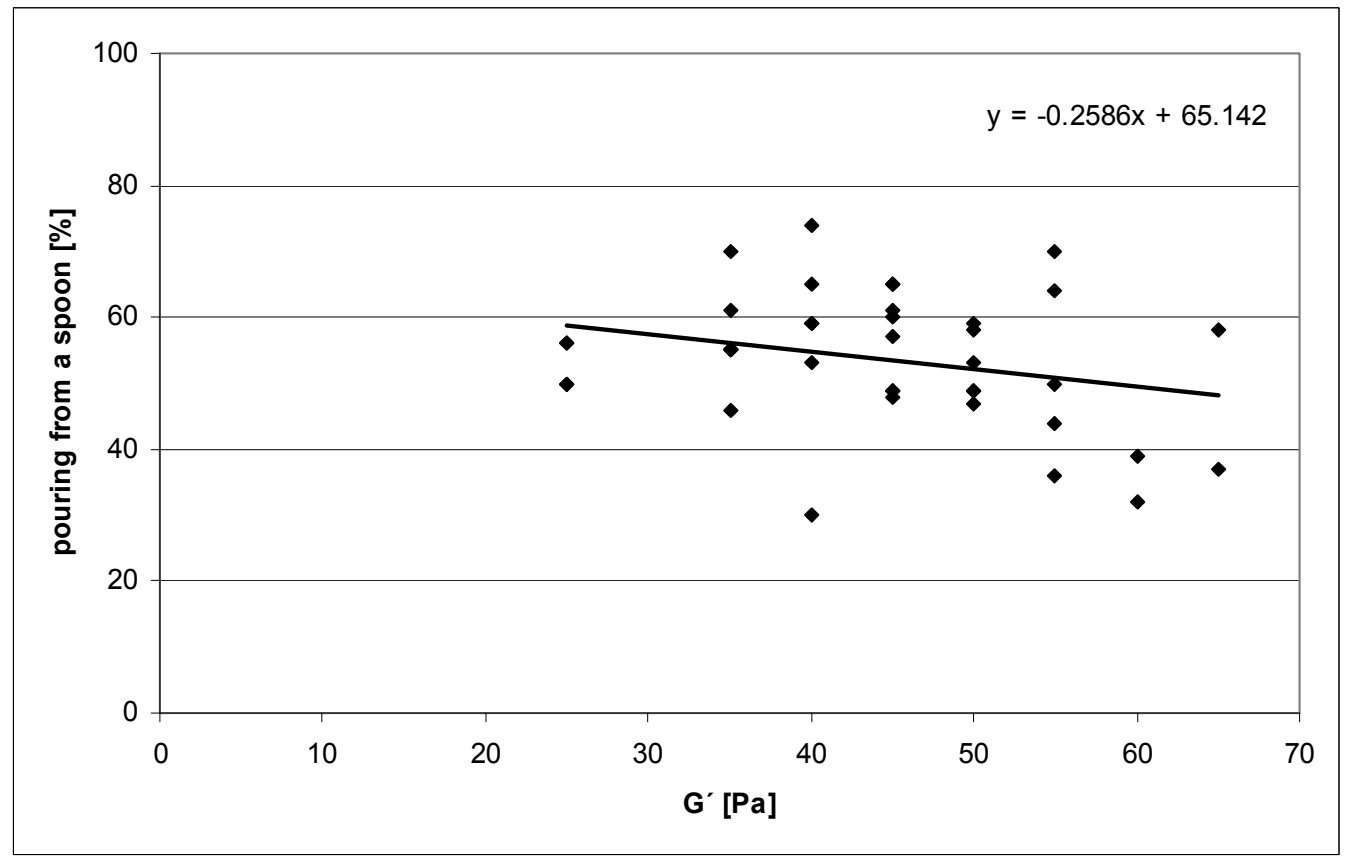

Fig. 5. Relationship between the storage modulus and the resistance against pouring the sample from a spoon. Obr. 5. Vztah mezi pamět'ovým modulem $G^{\prime}$ a odporem proti stékání vzorku se lžíce. 


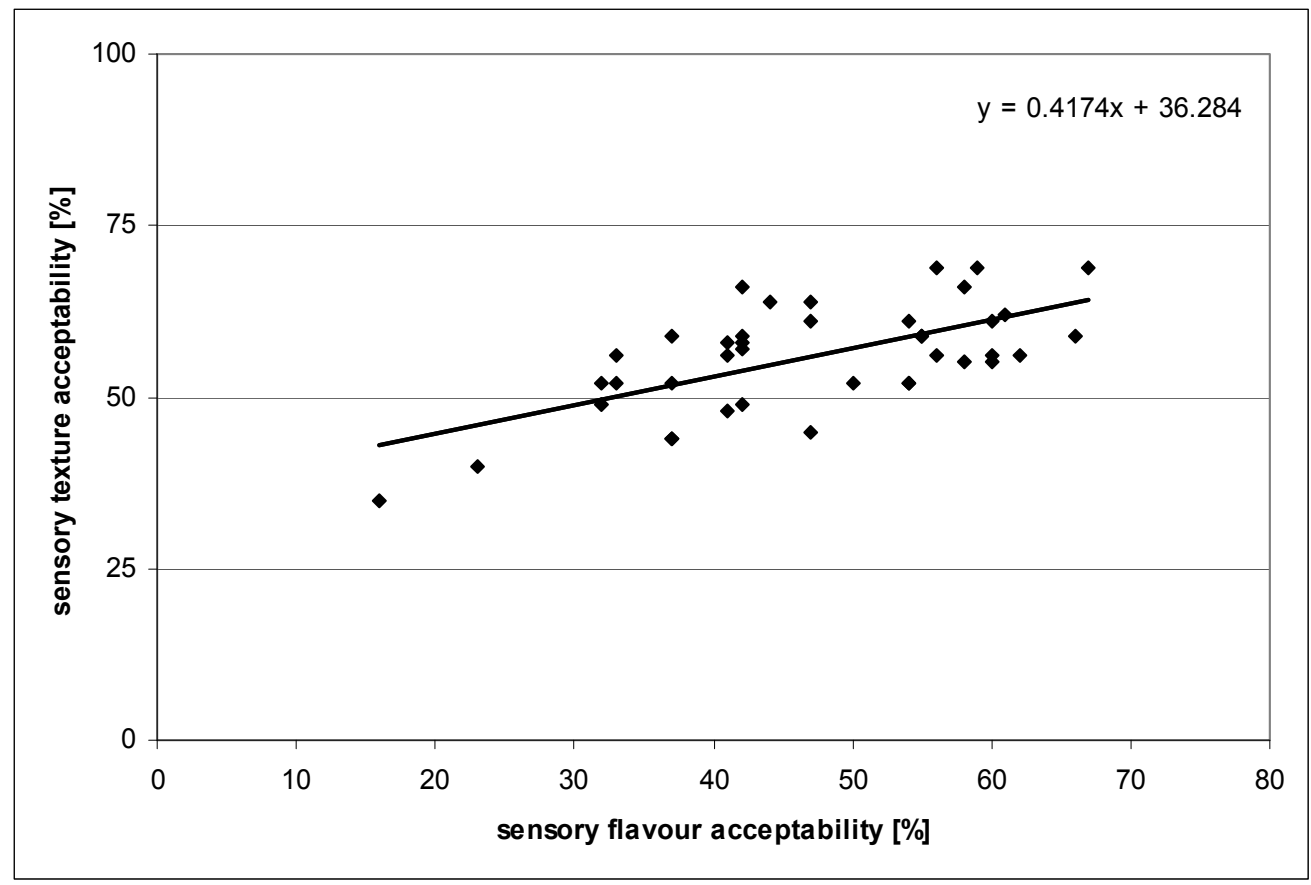

Fig. 6. Relationship between the sensory texture acceptability and overall flavour acceptability. Obr.6. Závislost mezi senzorickou texturou a přijatelností chuti.

\section{Conclusions}

A set of 20 commercial ketchups was tested at two temperatures with several rheological methods and sensory profiling. Great differences were observed among samples but still many statistically significant relationships were found on statistic evaluation partially also between rheological and sensory characteristics. These differences would become more pregnant if lower temperature is included in the measurements. Similarly as in case of lipid dispersions close relation between the sensory texture acceptability and overall flavour acceptability were observed. In some cases the rheological measurement can predict the sensory attribute.

Acknowledgements. The support under the project No. IAA2060404 by the Grant Agency of the Academy of Sciences of the Czech Republic is gratefully acknowledged.

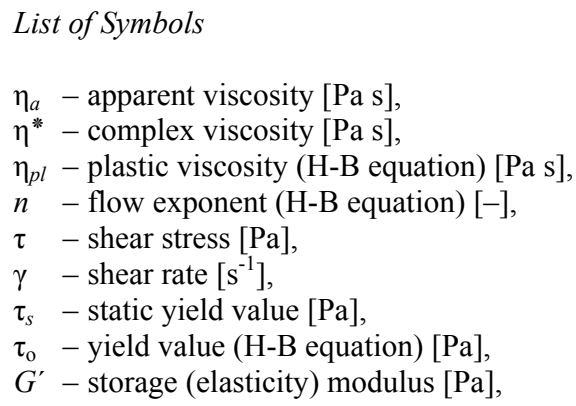

$G^{\prime \prime}-$ loss (viscosity) modulus [Pa],

$G^{*}$ - complex elasticity modulus $[\mathrm{Pa}]$,

$t$ - time [min].

\section{REFERENCES}

AUTIO K., HOUŠKA M., 1991: Measurement of flow curves for model liquids and real food systems with two commercial viscometers. Journal of Food Engineering, 13, 57-66.

BARNES H.A., 1999: Yield stress - a review, or panta rei everything flows? Journal of Non-Newtonian Fluid Mechanics, 81, 1\&2, 133-178.

BRUMMER R., 2006: Rheology Essentials of Cosmetic and Food Emulsions. Chapter 13. In: Excursion in the World of Food Rheology. Springer-Verlag, Berlin, Heidelberg, p. 165.

HERSCHEL W.H., BULKLEY R., 1926: Measurement of consistency as applied to rubber benzene solutions. KolloidZeitschrift, 39, p. 291.

ROBERTS I., 2003: In-line and on-line rheology measurement of food. In: B. M. McKENNA (Ed.) Texture in Food. Vol. 1. Semi-solid Foods, Woodhead Publishing, Cambridge, UK, pp. 161-182.

SAHIN H., OZDEMIR F., 2004: Effect of some hydrocolloids on the rheological properties of different formulated ketchups. Food Hydrocolloids, 18, 1015-1022.

STEFFE J.E., 1996: Rheological methods in Food Process Engineering. Freeman Press, Still Valley Dr., p. 38, 202.

ŠTERN P., POKORNÝ J., DAVÍDEK J., ČMOLÍK J., 1988: Relations between rheological and sensory properties of fat foams. Rheologica Acta, 265, 457-458.

ŠTERN P., VALENTOVÁ H., POKORNÝ J., 2001: Rheological properties and sensory texture of margarines. European Journal of Lipid Science and Technology, 103, 23-28. 
ŠTERN P., POKORNÝ J., ŠEDIVÁ A., PANOVSKÁ Z., 2008: Rheological and sensory characteristics of yoghurt modified mayonnaise. Czech Journal of Food Science, 26, $110-118$.

ŠTERN P., PANOVSKÁ Z., POKORNÝ J., 2006: Psychorheology of tartar sauce. Journal of Texture Studies, 37, 580-596.

VARELA P., GAMBARO A., GIMÉNEZ A.M., DURAN I., LEMA P., 2003: Sensory and instrumental texture measures on ketchup made with different thickeners. Journal of Texture Studies, 34, 317-330.

Received 18 December 2008 Accepted 14 October 2009

\section{PSYCHOREOLOGIE POTRAVINÁŘSKÝCH DISPERZÍ}

Petr Štern, Zdeňka Panovská, Jan Pokorný

Psychoreologie zkoumá funkční závislosti mezi komplexními reologickými parametry, stanovenými instrumentálně metodou rotační reometrie a texturními ukazateli, stanovenými sensorickou analýzou. Znalost těchto psychoreologických zákonitostí je důležitá ke kvantitativní charakterizaci tokových a deformačních dějů, probíhajících při sensorické zkoušce. To umožní následnou instrumentální analýzu za reologicky srovnatelných podmínek. Ze zjištěné funkční závislosti lze komplexně charakterizovat texturu a stanovit rozmezí reologických parametrů, jež odpovídá optimálním užitným vlastnostem produktů.

Potravinářské disperze patří mezi nejrozšiřrenějšši potravinářské produkty. Potřebné informace k prezentovaným výsledkům předloženého studia byly získány předchozím studiem potravinářských disperzí (emulgované tuky, majonézy, dresinky). Kečupy byly vybrány jako př́klad potravinářských disperzí s nízkým obsahem tuku. Při 23 a $45{ }^{\circ} \mathrm{C}$ byla analyzována řada 20 kečupů, odebraných na domácím trhu. Reologické charakteristiky (mez toku, zdánlivá, plastická a komplexní viskozita, tixotropie, pamětový, ztrátový a komplexní modul) byly stanoveny s použitím reometru RheoStress 300 (Thermo Haake, Karlsruhe, Německo). Statická mez toku byla stanovena pomocí „vane rotoru“ a ostatní reologické parametry v rýhovaných koaxiálních válcích $\mathrm{k}$ zamezení skluzu na stěnách měřících válců.

Při sensorické analýze byly testovány: vzhled, barevný odstín, odpor k nabírání lžící, snadnost stékání se lžíce, viskozita po vložení do úst, odpor při přitlačení jazykem k patru, přijatelnost textury, intenzita kořenění, přijatelnost chuti, palčivost po spolknutí a chut' na bramborových hranolcích.

Byl získán značný počet reologických údajů. Bylo zjištěno, že kečupy jsou z reologického hlediska tixotropní viskoplastické látky a zjištěné reologické parametry vyhovují reologickému modelu Herschel-Bulkley $\tau=$ $=\tau_{\mathrm{o}}+\eta_{p l} \cdot \gamma^{n}$ (dále jen H-B model). Tixotropní charakter sledovaných kečupů byl jednoznačně prokázán pomocí dynamické oscilační reometrie. Mezi stanovenými reologickými parametry existují těsné, zpravidla lineární funkční vztahy $\left(\mathrm{R}^{2}=0,95-0,99\right)$.

Analýzy prokázaly velké rozdíly mezi jednotlivými vzorky kečupů. Přesto počet významných funkčních závislostí $(\mathrm{P}=0,05)$ mezi reologickými a sensorickými parametry byl překvapivě vysoký (ze 141 proměnných bylo 58 statisticky významných). Většina funkčních vztahů byla lineární nebo velmi blízkých linearitě. Nebyla zjištěna závislost mezi statickou mezí toku a dalšími proměnnými. Stejně jako u tukových dispersí bylo zjištěno, že u spotřebitele textura ovlivňuje chut' výrobku. V řadě prŕpadů lze rychlou a objektivní rotačněreometrickou metodu i v prrípadě kečupů využít $\mathrm{k}$ předpovědi sensorických charakteristik.

\section{Seznam symboli̊}

$\eta_{a}$ - zdánlivá viskozita [Pa s],

$\eta^{*}$ - komplexní viskozita [Pa s],

$\eta_{p l}$ - plastická viskozita (H-B model) [Pa s],

$n$ - exponent toku (H-B model) [-],

$\tau-$ smykové napětí [Pa],

$\gamma \quad$ - smyková rychlost $\left[\mathrm{s}^{-1}\right]$,

$\tau_{s}-$ statická mez toku $[\mathrm{Pa}]$,

$\tau_{\mathrm{o}}-$ mez toku (H-B model) [Pa],

$G^{\prime}$ - pamět'ový (elastický) modul [Pa],

$G^{\prime \prime}$ - ztrátový (viskózní) modul [Pa],

$G^{*}$ - komplexní modul $[\mathrm{Pa}]$,

$t$ - čas [min]. 